\title{
Fin de NAIL: New Approaches to International Law and its Impact on Contemporary International Legal Scholarship
}

Keywords: Critical Legal Studies Movement; New Approaches to International Law.

Intellectual clashes over the nature of international law have been raging throughout the traceable history of the discipline. Naturalists, positivists, idealists, pragmatists, formalists, realists, and so forth, have striven to put forward and defend credible paradigms of international legal order. The common characteristic of each new wave of criticism has been its unsettling disposition. It arrived stridently with questions and doubts, often seeking reform and often reconceptualization and transcendence. A second common characteristic, notably in the post-enlightenment period, has been the marginalized position of the debate on the merit of each new wave, within and outside legal academia. Indeed, debate over unsettling questions seems to have been exempted from the habitual professional responsibilitics of the overwhelming majority of international lawyers. Existential anxieties of this sort have been relinquished to that class of academics usually referred to as jurisprudes or legal theorists. 'Practicing' international lawyers, so it is often argued, need not concern themselves with 'theory'. Their mission is to provide tangible answers to practical problems and, for this task, 'theoretical' debate is irrelevant: its outcome is indeterminate, abstract, and, thus, of limited usability. In some cases 'theoretical' even becomes a pejor-

1. The marginalization of 'theoretical' debate has been noticed by many writers: see, e.g., M. Koskenniemi, From Apology to Utopia - The Structure of International Legal Argument xiii (1989): see. generally. P. Allott et al., Thenry and Internatinnal I aw: An Introduction (1991). 
ative term, synonymous with counter productive or parasitic. ${ }^{2}$

The 'unsettling jurisprudes' of each generation, on the other hand, have another mission in mind. Although they also enjoy problem-solving, they believe that they perceive both the problem and the solution differently from their predecessors. They are guided by a compelling insight according to which contemporary scholarship is perceived as lacking transformative potential, hence their feeling of disenchantment with the state of the discipline. In their academic institutions, civil service, or wherever else they happen to be, they experience this dissatisfaction daily and they want to reinvigorate and rehabilitate international law. They embark on a project aimed at exposing the fallacies of the preceding disciplinary generation(s); they plead for reform and, sometimes, for a radical reinvention of the field. At first their argument is crude and subversive, primarily directed at revealing the misconceptions of - what they see as - the mainstream. With the passing of time, some develop a more refined and idiosyncratic language, style, argument, and objectives. They grow in numbers and establish strongholds, networks, leading exponents, publications.

The mainstream feels vexed by the critique and, frankly speaking, quite estranged. The new language is baffling and inappropriate; the style patronizing and arrugant; the argument imperceptivc and tawdry; the objectives far-fetched. The whole thing simply goes too far! Few members of the potential professional audience are going to respond, even fewer meaningfully. They are piqued by the audaciousness of the newcomers and, additionally, busy with solving pressing 'practical' problems, there is little time for abstract discussions. They will allow their 'own' jurisprudes to fend off the attack. Indeed, some of 'their' jurisprudes will. The newstream critique, however, if not substantially criticized by and confronted with the majority of international lawyers, will remain marginal, peripheral. The 'practitioners', after an occasional look at the debate, will eventually turn away disinterested and somehow reassured that their principles are well defended. Unless the ice of communication is broken, the new critique's

2. In a characteristic statement, while speaking of recognition of states in international law, Brownlie argues that ${ }^{\circ}[t]$ here is no doubt room for a whole treatise on the harm caused to the business of legal investigation by theory. [...] Theory has not only failed to enhance the subject but has created a tertium quid which stands, like a bank of fog on a still day, between the observer and the contours of ground which calls for investigation". See I. Brownlie, Recognition in Theory and Practice, in R.St.J. MacDonald \& D.M. Johnston (Eds.), The Structure and Process of International Law 627 (1986). 
transformative potential will slowly be defused and any valuable insight will remain unexploited.

The motivation for this Editorial was the recent Conference on New Approaches to International Law, which took place last May at Harvard University. ${ }^{3}$ The label New Approaches to International Law (NAIL) was coined in the early 1990s to capture the spirit of a new stream of international legal scholarship, inspired by critical theory and engaged in an ambitious project of reimagining international law. NAIL has never been an intellectual 'movement' in the usual meaning of the term, pussessing a formal organizational structure, newsletters, etc. It has rather been a rubric under which people with common sensibilities about international law have been exchanging views and experiences. ${ }^{4}$ 'T 'The Harvard Conference came to evaluate the progress made so far and to celebrate the abandonment of the appellation NAIL as the form representing the ever-evolving new stream of international legal investigation. Despite the achievements so far, anchoring newstream writing to the label and practices of NAIL for too long would ultimately defeat its objectives. At the closing session of the Conference, it was emphasized that one of the most important tasks for the future newstream writing will be to bridge the communication gap with the mainstrcam.

Even a quick look confirms the view that NAIL fulfils the criteria of 'unsettling jurisprudence'. It challenged on all levels the prevailing conception of international law. It pleaded for reinventing international law, recasting the foundations of legal science, shaking academic complacency, and redeeming imagination and self-criticism on the part of the international lawyer. Its sensibilities are diverse. With proponents engaged in projects ranging as widely as post-colonialism, third world approaches to international law, feminist critique, post-modern economic law, history of international law, ethics of the international lawyer, etc., the NAIL-ers have presented a voluminous bibliography and a challenge to all fronts. ${ }^{5}$

3. Conference on New Approaches to International Law: Fin de NAIL: A Celebration, Harvard Law School, 8-11 May 1997.

4. For some representative accounts of newstream writing see, e.g., D.Z. Cass, Navigating the Newstream: Recent Critical Scholarship in International Law, 65 Nordic Journal of International Law 341-383 (1996); D. Kennedy, A New Stream of International Law Scbolarship, 7 Wisconsin International Law Journal 1-49 (1988-1989); and A. Carty, Critical International Law: Recent Trends in the Theory of International Law, 2 EJIL 66-96 (1991).

5. For the most extensive newstream bibliography compiled so far, see 1997 HILJ (forthcoming). 
Their use of language is conscious, sometimes casual and personal, other times literary, or overcast with philosophical jargon, but nevertheless deviating from the standard textbook word stocks. Their tone is engaged, at times reminiscent of missionary zeal, but often self-critical. Their methodology varies, depending on the individual and the type of the project pursued but, generally, it is influenced by critical theory and the philosophical movements of structuralism, post-structuralism, and deconstruction, formerly introduced to the legal domain by the Critical Legal Studies movement (CLS).

In a nutshell, ${ }^{6}$ the newstream critique challenges the assumptions underlying the conventional contemporary international legal scholarship, often described as the liberal conception of international law. Amongst others, the liberal conception of law maintains the possibility of distinguishing between political opinion and law. As presented in mainstream writing, law is distinct from politics or morals because law is neutral and because its content can be verified in a reliable and consistent fashion. Legal rules can be uniformly applied to an infinite number of circumstances. Newstream critique, on the other hand, rejects this view. For the newstream, international law (the same with law in general) is made of language. Linguistics has demonstrated that words do not have a natural hidden meaning which should be uncovered. Similarly, legal rules and concepts, made of language, possess no pre-existing meaning to be disclosed by the jurist. Rather, the meaning is imposed on the law in the act of interpretation. Therefore, legal interpretation is not an unpolitical, value-free exercise which simply reveals a pre-existing legal meaning. It is rather an inherently creative one, and creativity is so intrinsic to the act of interpretation that it cannot be waived by procedural rules and standards. Creativity, in turn, invites diversity in interpretation. This last conclusion is reminiscent of the familiar (realist) indeterminacy critique. The newstream, however, pursues the argument further. It suggests that, by generally endorsing the possibility of detcrminate interpretation, the liberal conception of law makes contradicting interpretations justifiable. Based on various 'objectively' founded premises, jurists make 'objective' arguments which are invariably incompatible with each other and mutually exclusive. At the

6. Providing a 'nutshell' account of newstream writing is a self-defeating exercise, involving generalizations ill-suited to the description of the work of such a diverse group of writers, but it is prompted here by space considerations. For some comprehensive accounts see note 4, supra. 
same time, these arguments can find justification within the system. By reaching mutually exclusive (but equally justified) positions, the debate becomes indeterminate, lacking common ground to be found between the conflicting positions. This pattern has been graphically described by Martti Koskenniemi as the oscillation of the legal argument between apology and utopia. ${ }^{7}$

The potential of this critique may be enormous, and some aspects are already being investigated by NAIL writers. ${ }^{8}$ To mention one, the realization that legal concepts are not unpolitical, triggers a series of unsettling questions over the usefulness of interminable definitional struggles over concepts such as state sovereignty, sources of law, human rights, self-determination, culture, and so on. Additionally, in a discipline where legal reasoning and legal interpretation are not mechanical exercises, the jurist is confronted with new limits and possibilities. In order to achieve this s/he must first become conscious of and then develop a vision of how to utilize them. This involves primarily an investigation of the self, a redefinition of one's (professional and personal) identity and responsibility.

International lawyers have felt quite perplexed with the newstream critique. The messianic tone of some of the writers is certainly annoying and quite inappropriate for legal writing, isn't it? The language is admittcdly rich but stilted: couldn't the same arguments be articulated in a simpler way? Regarding their substantive claims there is extreme reservation. The method appears nihilist; where else does deconstruction lead, other than to the elimination of international law? The critique of law's objectivity reduces law to politics and eliminates the role of the international lawyer. If the newstream model suggests that every legal rule is subjective and indeterminate, how are states restrained from behaving as they please? Does the risk of creating anarchy and disorder reappear? Unfortunately, most of these protests have been exhausted in discussions in university corridors, the odd conference panel, and a few sporadic article-length contributions. ${ }^{10}$ Despitc the growth in NAIL writing, engaged scholarly response

7. See Koskenniemi, supra note 1.

8. The parh-breaking works of $\mathrm{D}$. Kennedy and $\mathrm{P}$. Allort provide some good examples. See D. Kennedy, International Legal Structures (1987); and P. Allott, Eunomia: New Order for a New World (1990).

9. For some exploratory efforts on this front, see O. Korhonen, New International Law: Silence, Defence or Deliverance?, / EJIL 1-28 (1946); and M. Koskenniemi, Faith, Identity, and the Killing of the Innocent: International Laweryers and Nuclear Weapons, 10 LJIL 137.162 (1997).

10. See, e.g., I. Scobbie, Towards the Elimination of International Law: Some Radical Scepticism 
has been spectacularly absent. This is not to say that the critique has been totally ignored. Some recent textbooks make brief references to 'new approaches' but, in the long run, those references are distanced and superficial, not containing a meaningful response. ${ }^{11}$ The overwhelming majority of international lawyers has either never heard of the newstream critique or has not formed an idea about its claims.

The present note is an invitation to debate. It does not intend to convince regarding the validity of the newstream critique, but only to point at ir. NAIL has not got it all right. Newstrean critique is involved in a project of reimagining international law and starts by pointing out recurrent patterns formerly unnoticed or unexploited. Reflection on that project and personal commitment to developing a meaningful response to it is the only way of evaluating (and exploiting) its potential. Subjecting oneself to such a process of critical evaluation has nothing to do with being either a 'jurisprude' or a 'practitioner'. It has to do with reflecting on one's (personal and professional) identity and responsibility.

Thomas Skouteris

About Sceptical Radicalism, 61 BYIL 339-362 (1990); J. Hasnas, Back to the Future: From Critical Legal Studies Forward to Legal Realism, or How Not to Miss the Point of the Indeterminacy Argument, 45 Duke Law Journal 84-132 (1995); and N. Purvis, Critical Legal Studies in Public International Law, 32 HILJ 81-127 (1991).

11. See M. Dixon, Textbook on International Law 17 (1990), in which he devotes eight lines to 'deconstructionist theories', dismissing their merit by suggesting that "any attempt to reach a conclusion about the nature of international law [...] is bound to fall foul of criticism of all sides". See also R. Higgins, Problems and Process - International Law and How We Use It 9.10 (1994), in which she devotes one page to rejecting the arguments of the "critical legal studies phenomenon"; see also a short commentary by the editors in L. Henkin et al. (Eds.), International Law: Cases and Materials 48-49 (1993). Some sympathetic references can also be found in N.D. White, The Law of International Organizations 18-22 (1996); and R. Beck, A. Clark Arend \& R. Vander Lucht (Eds.), International Rules: Approaches From International Law and International Relations 227-229 (1996). 